\title{
AUDIT MANAJEMEN ATAS PENGELOLAAN PIUTANG USAHA PADA PT. PELABUHAN INDONESIA IV (PERSERO) CABANG SAMARINDA
}

\section{Oleh:}

Muhammad Adhani Adhitaqwan', Mardiana ${ }^{2}$, dan Camelia Verahastuti ${ }^{3}$

${ }^{1}$ Mahasiswa Fakultas Ekonomi Universitas 17 Agustus 1945 Samarinda,

2 dan ${ }^{3}$ Dosen Fakultas Ekonomi Universitas 17 Agustus 1945 Samarinda m.adhaniadhitaqwan123@gmail.com

\section{ABSTRACT}

The purpose of this research is to know whether management audit implementation as financial function toward ship service accounts receivable management in PT. Pelabuhan Indonesia IV (Persero) Samarinda branch is effective. The analysis instrument was comparative method, this method was done by collecting and explaining non-numeric data (qualitative) and then it was compared with relevant theories to get result clarity which can be resulted as conclusion and suggestion. The result of the research analysis showed that management audit implementation as financial function toward ship service accounts receivable management in PT. Pelabuhan Indonesia IV (Persero) Samarinda branch was less effective. The conclusion of this research was there were some flaws in ship service accounts receivable management which needs to be fixed to improve company efficacy.

Keywords: Management Audit, Accounts Receivable Management, Accounts Receivable Management Efficacy

\section{PENDAHULUAN}

Perkembangan dunia usaha di Indonesia saat ini tak lepas dari peranan pihak perusahaan swasta seperti Penanaman Modal Dalam Negeri (PMDN) dan Penanaman Modal Asing (PMA) maupun Badan Usaha Milik Negara (BUMN) dan Badan Usaha Milik Daerah (BUMD) yang bergerak di berbagai bidang sangat membantu dalam perekonomian di Indonesia. Setiap perusahaan yang bergerak di bidang dagang, jasa maupun manufaktur memiliki tujuan yang sama, yaitu memperoleh laba dan mensejahterakan karyawannya serta menjaga kesinambungan perusahaan di masa yang akan 
datang. Untuk mempertahankan itu semua perusahaan harus memiliki manajemen keuangan yang baik.

Manajemen keuangan mempunyai peran yang strategis dalam pengambilan keputusan yang berkaitan dengan investasi, operasi, pendanaan, dan pengelolaan aktiva perusahaan. Mengingat pentingnya manajemen keuangan yang baik, maka biasanya dalam struktur organisasi perusahaan selalu ada satuan unit kerja tersendiri yang khusus menangani bagian keuangan.

Bagian keuangan suatu perusahaan bertugas untuk mengumpulkan, menganalisis, dan memantau data yang diperoleh dari satuan kerja dan fungsional bidang lainnya untuk membuat suatu pelaporan keuangan yang mudah dipahami dan mudah digunakan pihak-pihak yang bersangkutan. Bagian keuangan harus mampu menganalisis setiap laporan yang masuk dari bidang fungsional lain dan membuat perencanaan keuangan dengan baik agar dapat menghindari terjadinya pemborosan dana dalam perusahaan. Pentingnya tugas satuan kerja bidang keuangan membuat pengendalian dan pengawasan kerja ini menjadi penting, oleh karena itu dibutuhkan alat untuk menilai kinerja satuan yang mengurus bidang keuangan perusahaan. Salah satunya adalah audit manajemen.

Audit manajemen dapat dilakukan pada beberapa aspek yang meliputi audit manajemen fungsi keuangan, fungsi pemasaran, fungsi pengadaan, fungsi sumber daya manusia, fungsi produksi dan operasi, dan audit perpajakan. Salah satu fungsi audit manajemen yang memiliki peran penting yaitu departemen keuangan. Kegiatan operasional dan biaya yang ada begitu kompleks sehingga peran departemen keuangan menjadi sangat penting. Informasi dari fungsi keuangan menjadi input penting manajemen tingkat atas dalam proses pengambilan keputusan kinerja perusahaan. Audit manajemen atas suatu proses pemeriksaan secara sistematis yang dilaksanakan untuk mendapatkan dan mengevaluasi bukti secara objektif atas prosedur-prosedur dan kegiatan manajemen keuangan.

PT. Pelabuhan Indonesia IV (Persero) Cabang Samarinda adalah salah satu Badan Usaha Milik Negara (BUMN) yang bergerak di bidang jasa kepelabuhanan. Perusahaan ini mengelola pelabuhan laut sesuai dengan sifat usahanya yaitu menyediakan, melaksanakan, dan mengusahakan pelayanan jasa bagi kegiatan lalu lintas angkutan laut. Jasa yang dijual oleh perusahaan berupa pelayanan kapal, pelayanan barang, pengusahaan alat, pelayanan $\mathrm{B} / \mathrm{M}$ terminal konvensional, pelayanan terminal petikemas, pengusahaan tanah, bangunan dan lainnya, kerjasama pengoperasian.

Prosedur keuangan yang ada di PT. Pelabuhan Indonesia IV (Persero) Cabang Samarinda meliputi transaksi penjualan jasa secara tunai dan kredit. Penjualan jasa secara tunai tentu akan langsung menghasilkan kas, berbeda dengan penjualan jasa secara kredit yang tidak langsung menghasilkan kas 
tetapi akan menimbulkan piutang bagi perusahaan. Semua bidang pelayanan jasa kepelabuhanan yang ada pada perusahaan dapat dibayar secara kredit, namun pada penelitian ini peneliti hanya menganalisis bidang pelayanan jasa kapal. Pelayanan jasa kapal yang dibayar secara kredit ini ternyata menimbulkan masalah bagi pihak perusahaan, yaitu tingginya jumlah piutang usaha akibat dari banyaknya piutang usaha tidak lancar. Menurut informasi yang diterima dari karyawan perusahaan, setiap harinya cukup banyak pengguna jasa yang menggunakan pelayanan jasa kapal secara kredit namun pengguna jasa tersebut sering terlambat dalam pembayaran piutangnya. Perusahaan telah memberikan kebijakan kepada pengguna jasa dalam pelaksanaan pelunasan piutang yaitu memberikan waktu selama 8 (delapan) hari setelah tanggal nota diterima. Namun pada realisasinya, terdapat beberapa pengguna jasa yang terlambat dalam melaksanakan pelunasan piutang dari waktu yang telah ditentukan. Selain itu, adanya rangkap jabatan oleh penanggung jawab piutang usaha yang juga sebagai bagian penagihan. Menurut informasi yang diterima dari karyawan perusahaan, penanggung jawab piutang usaha yang juga sebagai bagian penagihan kurang maksimal dalam melakukan pekerjaannya, seperti sering terlambatnya melakukan konfirmasi piutang usaha dan juga sering terlambatnya melakukan penagihan kepada para pengguna jasa yang telah melewati batas waktu pembayaran yang sudah ditetapkan perusahaan.

Berdasarkan hal tersebut, maka penulis tertarik untuk menganalisis aktivitas pengelolaan piutang usaha pelayanan jasa kapal pada PT. Pelabuhan Indonesia IV (Persero) Cabang Samarinda menggunakan audit manajemen agar dapat diketahui apakah aktivitas pengelolaan piutang usaha pelayanan jasa kapal tersebut sudah efektif.

\section{KERANGKA DASAR TEORI}

\section{Audit}

Menurut Agoes (2017:4), audit adalah suatu pemeriksaan yang dilakukan secara kritis dan sistematis, oleh pihak yang independen, terhadap laporan keuangan yang telah disusun oleh manajemen, beserta catatancatatan pembukuan dan bukti-bukti pendukungnya, dengan tujuan untuk dapat memberikan pendapat mengenai kewajaran laporan keuangan tersebut.

\section{Audit Manajemen}

Menurut Bhayangkara (2015:2), audit manajemen (management audit) adalah evaluasi terhadap efisiensi dan efektivitas operasi perusahaan. Dalam konteks audit manajemen, manajemen meliputi seluruh operasi internal perusahaan yang harus dipertanggungjawabkan kepada berbagai pihak yang memiliki wewenang yang lebih tinggi. Audit manajemen 
dirancang secara sistematis untuk mengaudit aktivitas, program-program yang diselenggarakan, atau sebagian dari entitas yang bisa diaudit untuk menilai dan melaporkan apakah sumber daya dan dana telah digunakan secara efisien, serta apakah tujuan dari program dan aktivitas yang telah direncanakan dapat tercapai dan tidak melanggar ketentuan aturan dan kebijakan yang telah ditetapkan perusahaan.

\section{Tujuan dan Manfaat Audit Manajemen}

Menurut Agoes (2019:184), tujuan audit manajemen adalah untuk:

1. Menilai kinerja dari manajemen dan berbagai fungsi dalam perusahaan.

2. Menilai apakah berbagai sumber daya (manusia, mesin, dana, harta lainnya) yang dimiliki perusahaan telah digunakan secara efisien dan ekonomis.

3. Menilai efektivitas perusahaan dalam mencapai tujuan yang telah ditetapkan oleh top management.

4. Dapat memberikan rekomendasi kepada top management untuk memperbaiki kelemahan-kelemahan yang terdapat dalam penerapan pengendalian intern, sistem pengendalian manajemen, dan prosedur operasional perusahaan, dalam rangka meningkatkan efisiensi, keekonomisan, dan efektivitas dari kegiatan operasi perusahaan.

\section{Ruang Lingkup dan Sasaran Audit Manajemen}

Ruang lingkup dalam audit manajemen dapat berupa seluruh kegiatan atau hanya mencakup bagian tertentu dari program/aktivitas yang dilakukan. Sementara yang menjadi sasaran dalam audit manajemen adalah kegiatan, aktivitas, program, dan bidang dalam perusahaan yang masih memerlukan perbaikan/peningkatan, baik dari segi ekonomisasi, efisiensi, dan efektivitas.

Menurut Bhayangkara (2015:28), ada tiga elemen penting dalam sasaran audit:

1. Kriteria

Merupakan norma, standar, atau sekumpulan standar yang menjadi panduan setiap individu (kelompok) dalam melakukan aktivitasnya sebagai pelaksana atas wewenang dan tanggung jawab yang diberikan padanya. Standar atau norma ini dipergunakan untuk menilai aktivitas atau hasil aktivitas dari setiap individu atau kelompok pada objek audit. Kriteria dapat berupa standard operating procedure (SOP), job description, peraturan perusahaan, rencana bisnis atau petunjuk pelaksanaan suatu aktivitas dan standar evaluasinya, serta bentuk-bentuk lain yang mungkin sesuai dengan karakteristik objek audit.

2. Penyebab

Merupakan tindakan atau aktivitas aktual yang dilakukan oleh setiap individu (kelompok) yang terdapat pada objek audit. 


\section{Akibat}

Merupakan hasil pengukuran dan pembandingan antara aktivitas individu (kelompok) dengan kriteria yang telah ditetapkan terhadap aktivitas tersebut.

Fungsi manajerial juga termasuk ke dalam ruang lingkup audit manajemen yang mengatur aktivitas-aktivitas agar sesuai dengan rencana yang telah ditetapkan organisasi sesuai dengan tujuannya. Menurut Bhayangkara (2015:18) pada fungsi manajerial, audit dilakukan terhadap perencanaan, pengorganisasian, pengarahan, dan pengendalian, berikut penjelasannya:

1. Perencanaan (planning)

Perencanaan merupakan tahap yang paling krusial dalam keberhasilan perusahaan. Pada tahap ini, komitmen manajemen dalam mengaktualisasikan profesionalismenya diuji. Apakah rencana telah mencerminkan:

a. Komitmen manajemen untuk membawa perusahaan ke arah yang lebih baik.

b. Tingkat produktivitasnya yang maksimal dari pengelolaan sumber daya yang dimiliki perusahaan.

c. Rencana-rencana peningkatan berkelanjutan yang dicanangkan manajemen untuk mencapai kinerja terbaik perusahaan.

Ketiga hal ini (walaupun tidak terbatas pada hal ini) merupakan hal penting yang harus diperhatikan dalam menilai perencanaan. Kecenderungan manajemen untuk membuat rencana dengan target peningkatan yang minimal adalah salah satu bentuk perilaku manajemen yang kurang kreatif. Target yang terlalu rendah tidak memberi tantangan terhadap kinerjanya, sehingga tidak memberi manfaat yang maksimal kepada perusahaan dibandingkan dengan sumber daya yang tersedia dan peluang yang dimiliki perusahaan.

2. Pengorganisasian (organizing)

Pengorganisasian menyangkut bagaimana pengaturan sumber daya dilakukan termasuk penempatan personel pada pekerjaan yang tepat sesuai dengan kompetensinya. Di samping itu, pengorganisasian juga berkaitan dengan pengalokasian sumber daya yang proporsional untuk mendukung penerapan strategi pencapaian tujuan perusahaan. Audit pada tahap ini lebih menekankan pada apakah sumber daya telah teralokasikan dengan tepat, sehingga setiap sumber daya yang dimiliki perusahaan dimanfaatkan secara optimal? Apakah tugas, wewenang, dan tanggung jawab telah diorganisasi dengan tepat dan dipegang oleh personel yang kompeten di bidangnya untuk menjamin efektivitas organisasi dalam mencapai tujuan. 


\section{Pengarahan (actuating)}

Pengarahan berkaitan dengan implementasi rencana, didukung oleh perangkat organisasi dan sumber daya yang memadai. apakah aktivitas operasional telah sesuai dengan prosedur dan aturan yang berlaku? Apakah setiap individu dan/atau kelompok telah menjalankan tugas wewenang dan tanggung jawabnya dengan baik sesuai dengan tugas pokok dan fungsi yang melekat padanya, adalah informasi penting yang harus diperoleh auditor dalam menilai efektivitas pengarahan dalam perusahaan.

4. Pengendalian (controlling)

Audit atas pengendalian menekankan pada penilaian terhadap efektivitas sistem pengendalian dalam memandu proses operasional agar mampu berjalan secara ekonomis, efisien, dan efektif dalam pencapaian tujuannya. Pada audit bagian ini, di samping mengevaluasi kecukupan sistem pengendalian, auditor juga menilai ketaatan penerapan sistem pengendalian tersebut dalam menjamin proses operasional yang selalu berjalan sesuai pedoman dan pada kondisi yang terkendali.

\section{Tahap-Tahap Audit Manajemen}

Menurut Bhayangkara (2015:11), secara garis besar tahapan-tahapan itu dapat dikelompokkan menjadi lima, yaitu audit pendahuluan; review dan pengujian pengendalian manajemen; audit terinci, pelaporan, dan tindak lanjut. Berikut penjelasannya:

1. Audit Pendahuluan

Audit pendahuluan dilakukan untuk mendapatkan informasi latar belakang terhadap objek yang diaudit. Di samping itu, pada audit ini juga dilakukan penelaahan terhadap berbagai peraturan, ketentuan, dan kebijakan berkaitan dengan aktivitas yang diaudit, serta menganalisis berbagai informasi yang telah diperoleh untuk mengidentifikasi hal-hal yang potensial mengandung kelemahan pada perusahaan yang diaudit. Dari informasi latar belakang ini, auditor dapat menentukan beberapa tujuan audit sementara.

2. Review dan Pengujian Pengendalian Manajemen

Pada tahapan ini auditor melakukan review dan pengujian terhadap pengendalian manajemen objek audit, dengan tujuan untuk menilai efektivitas pengendalian manajemen dalam mendukung pencapaian tujuan perusahaan. Dari hasil pengujian ini, auditor dapat lebih memahami pengendalian yang berlaku pada objek audit sehingga dengan lebih mudah dapat diketahui potensi-potensi terjadinya kelemahan pada berbagai aktivitas yang dilakukan. Jika dihubungkan dengan tujuan audit sementara yang telah dibuat pada audit pendahuluan, hasil pengujian pengendalian manajemen ini dapat 
mendukung tujuan audit sementara tersebut menjadi tujuan audit yang sesungguhnya (definitive audit objective), atau mungkin ada beberapa tujuan audit sementara yang gugur, karena tidak cukup (sulit memperoleh) bukti-bukti untuk mendukung tujuan audit tersebut.

3. Audit Terinci

Pada tahap ini auditor melakukan pengumpulan bukti yang cukup dan kompeten untuk mendukung tujuan audit yang telah ditentukan. Pada tahap ini juga dilakukan pengembangan temuan untuk mencari keterkaitan antara satu temuan dengan temuan yang lain dalam menguji permasalahan yang berkaitan dengan tujuan audit. Temuan yang cukup, relevan, dan kompeten dalam tahap ini disajikan dalam suatu kertas kerja audit (KKA) untuk mendukung kesimpulan audit yang dibuat dan rekomendasi yang diberikan.

4. Pelaporan

Tahapan ini bertujuan untuk mengkomunikasikan hasil audit termasuk rekomendasi yang diberikan kepada berbagai pihak yang berkepentingan. Hal ini penting untuk meyakinkan pihak manajemen (objek audit) tentang keabsahan hasil audit dan mendorong pihak-pihak yang berwenang untuk melakukan perbaikan terhadap berbagai kelemahan yang ditemukan. Laporan disajikan dalam bentuk komprehensif (menyajikan temuan-temuan penting hasil audit untuk mendukung kesimpulan audit dan rekomendasi). Rekomendasi harus disajikan dalam bahasa yang operasional dan mudah dimengerti serta menarik untuk ditindaklanjuti.

5. Tindak Lanjut

Sebagai tahap akhir dari audit manajemen, tindak lanjut bertujuan untuk mendorong pihak-pihak yang berwenang untuk melaksanakan tindak lanjut (perbaikan) sesuai dengan rekomendasi yang diberikan. Auditor tidak memiliki wewenang untuk mengharuskan manajemen melaksanakan tidak lanjut sesuai dengan rekomendasi yang diberikan. Oleh karena itu, rekomendasi yang disajikan dalam laporan audit seharusnya sudah merupakan hasil diskusi dengan berbagai pihak yang berkepentingan dengan tindakan perbaikan tersebut. Suatu rekomendasi yang tidak disepakati oleh objek audit akan sangat berpengaruh pada pelaksanaan tindak lanjutnya. Hasil audit menjadi kurang bermakna apabila rekomendasi yang diberikan tidak ditindaklanjuti oleh pihak yang diaudit.

\section{Fungsi Keuangan}

Menurut Bhayangkara (2015:325), fungsi keuangan merupakan fungsi yang paling penting dari suatu bisnis. Fungsi keuangan terkoneksi secara erat dengan fungsi produksi, pemasaran, dan aktivitas-aktivitas yang lain. 
Ketidakhadiran fungsi keuangan dapat menyebabkan semua aktivitas terhenti.

\section{Audit Manajemen Keuangan}

Menururt Bhayangkara (2015:327), audit manajemen keuangan adalah analisis dan penilaian yang dilakukan secara sistematis, periodik, dan terdokumentasi terhadap pengambilan keputusan serta segala kebijakan dalam pengelolaan sumber daya keuangan perusahaan.

\section{Piutang}

Menurut Agoes (2017:258), piutang adalah piutang yang berasal dari penjualan barang dagangan atau jasa secara kredit.

\section{Tujuan Audit Piutang}

Menurut Agoes (2017:258), audit piutang bertujuan untuk:

1. Mengetahui apakah terdapat pengendalian intern (internal control) yang baik atas piutang dan transaksi penjualan, piutang dan penerimaan kas.

2. Memeriksa apakah transaksi yang menyangkut penjualan, piutang, dan penerimaan kas:
a. Semuanya sudah dicatat secara akurat (completeness and accuracy).
b. Semuanya merupakan transaksi yang benar-benar terjadi. Tidak ada yang fiktif (occurancelexixtence).
c. Semuanya dicatat pada periode yang tepat (cut-off).

3. Memeriksa validity (keabsahan) dan authenticity (keotentikan) daripada piutang.

4. Memeriksa collectibility (kemungkinan tertagihnya) piutang dan cukup tidaknya perkiraan allowance for bad debts (penyisihan piutang tak tertagih).

5. Mengetahui apakah ada kewajiban bersyarat (contingent liability) yang timbul karena pendiskontoan wesel tagih (notes receivable).

6. Mengetahui apakah piutang yang tercantum dalam mata uang asing sudah dikonversi ke dalam rupiah dengan menggunakan kurs rupiah BI pada tanggal neraca.

7. Memeriksa apakah penyajian piutang dilaporan posisi keuangan (neraca) sesuai dengan standar akuntansi yang berlaku umum di Indonesia/Standar Akuntansi Keuangan/SAK ETAP (presentation and disclosures).

\section{Efektivitas}

Menurut Priansa dan Garnida (2013:11), efektivitas adalah pencapaian usaha yang sesuai dengan rencananya (doing the right things) atau rencana hasil dibandingkan dengan realisasi hasil. 


\section{III.METODE PENELITIAN}

Metode penelitian ini menggunakan pendekatan deskriptif kualitatif. Objek penelitian yang digunakan yaitu PT. Pelabuhan Indonesia IV (Persero) Cabang Samarinda yang beralamat di Jalan Niaga Timur No 130. Sebagai batasan penelitian dilakukan pada ruang lingkup manajemen keuangan khususnya pengelolaan piutang usaha pelayanan jasa kapal periode 2019. Pengumpulan data dilakukan melalui penelitian lapangan (field work research) yang terdiri dari wawancara kepada pihak-pihak yang terkait dengan masalah, observasi terhadap aktivitas dalam perusahaan yang berkaitan dengan masalah, dan daftar pertanyaan (questionnaires) untuk mendapatkan respon dari pihak-pihak yang berkaitan dengan masalah, kemudian penelitian kepustakaan (library research) dengan mengumpulkan data dari catatan-catatan, laporan-laporan, serta dokumen-dokumen yang terdapat pada PT. Pelabuhan Indonesia IV (Persero) Cabang Samarinda yang berkaitan dengan permasalahan.

Alat analisis yang digunakan adalah metode komparatif. Metode ini dilakukan dengan cara mengumpulkan dan menjelaskan data non angka (kualitatif) kemudian membandingkan dengan teori yang bersangkutan untuk memperoleh kejelasan hasil yang akan dijadikan sebagai simpulan dan saran. Perhitungan untuk mengetahui presentase skor hasil kusioner menggunakan rumus Dean J. Champion dalam Lucia Oktaviana (2015), yaitu dengan menjumlahkan jumlah jawaban "Ya/Tidak". Untuk jawaban "Ya" diberi skor 1 (satu) dan jawaban "Tidak" diberi skor 0 (nol). Jumlah jawaban tersebut kemudian dibandingkan dengan jumlah pertanyaan lalu dilakukan perhitungan menggunakan rumus berikut ini:

$$
\text { Presentase }=\frac{\sum \text { Jumlah Jawaban "Ya" }}{\sum \text { Jumlah Pertanyaan }} \times 100 \%
$$

Hasil presentase tersebut dideskripsikan dengan berdasarkan kriteria penilaian pada tabel berikut ini:

Tabel 1. Kriteria Penilaian Hasil Nilai Presentase

\begin{tabular}{|c|c|}
\hline Presentase & Kriteria \\
\hline $0 \%-25 \%$ & Tidak Efektif \\
\hline $26 \%-50 \%$ & Kurang Efektif \\
\hline $51 \%-75 \%$ & Cukup Efektif \\
\hline $76 \%-100 \%$ & Sangat Efektif \\
\hline
\end{tabular}

Sumber: Dean J. Champion dalam Lucia Oktaviana (2015) 


\section{ANALISIS DAN PEMBAHASAN}

\section{Analisis}

Tabel 2. Rekapitulasi Program Audit Manajemen Piutang

\begin{tabular}{|c|c|c|c|c|c|c|c|c|c|}
\hline \multirow[b]{2}{*}{$\begin{array}{c}\text { Responde } \\
\text { n }\end{array}$} & \multicolumn{7}{|c|}{ Pertanyaan } & \multicolumn{2}{|c|}{ Jawaban } \\
\hline & $\begin{array}{c}\text { Buti } \\
\mathbf{r} \\
\mathrm{Ke} 1\end{array}$ & $\begin{array}{c}\text { Buti } \\
\text { r } \\
\text { Ke } 2\end{array}$ & $\begin{array}{c}\text { Buti } \\
\text { r } \\
\text { Ke } 3\end{array}$ & $\begin{array}{c}\text { Buti } \\
\text { r } \\
\text { Ke } 4\end{array}$ & $\begin{array}{c}\text { Buti } \\
\text { r } \\
\text { Ke } 5\end{array}$ & $\begin{array}{c}\text { Buti } \\
\mathbf{r} \\
\text { Ke } 6\end{array}$ & $\begin{array}{c}\text { Buti } \\
\text { r } \\
\text { Ke } 7\end{array}$ & $\begin{array}{l}\mathbf{Y} \\
\mathbf{a}\end{array}$ & $\begin{array}{c}\text { Tida } \\
\mathbf{k}\end{array}$ \\
\hline $\mathrm{Ke} 1$ & 1 & 0 & 0 & 1 & 1 & 0 & 0 & 3 & 4 \\
\hline $\operatorname{Ke} 2$ & 1 & 0 & 0 & 1 & 1 & 0 & 0 & 3 & 4 \\
\hline $\operatorname{Ke} 3$ & 1 & 0 & 0 & 1 & 1 & 1 & 0 & 4 & 3 \\
\hline $\operatorname{Ke} 4$ & 1 & 0 & 0 & 1 & 1 & 0 & 0 & 3 & 4 \\
\hline Ke 5 & 1 & 0 & 0 & 1 & 1 & 0 & 0 & 3 & 4 \\
\hline $\operatorname{Ke} 6$ & 1 & 0 & 0 & 1 & 1 & 0 & 0 & 3 & 4 \\
\hline $\operatorname{Ke} 7$ & 1 & 0 & 0 & 1 & 1 & 0 & 0 & 3 & 4 \\
\hline $\operatorname{Ke~} 8$ & 1 & 1 & 0 & 1 & 1 & 0 & 0 & 4 & 3 \\
\hline \multicolumn{8}{|c|}{ Jumlah } & 26 & 30 \\
\hline
\end{tabular}

Sumber: Data Diolah Tahun 2020

Berdasarkan rekapitulasi program audit manajemen piutang tersebut dapat disimpulkan bahwa dari masing-masing 8 (delapan) responden yang diberikan 7 (tujuh) pertanyaan, maka diperoleh hasil jawaban sebanyak 56 (lima puluh enam) yang terdiri dari 26 (dua puluh enam) jawaban "Ya" dan 30 (tiga puluh) jawaban "Tidak". Berikut ini dilakukan perhitungan presentase menggunakan rumus Dean J. Champion dalam Lucia Oktaviana (2015) untuk menilai efektivitas pada program audit manajemen piutang tersebut:

Presentase $=\frac{\sum \text { Jumlah Jawaban "Ya" }}{\sum \text { Jumlah Pertanyaan }} \times 100 \%$

Presentase $=\frac{26}{56} \times 100 \%$

Presentase $=46,4 \%$

Pembahasan

Pengelolaan piutang usaha pelayanan jasa kapal pada PT. Pelabuhan Indonesia IV (Persero) Cabang Samarinda masih kurang efektif karena masih terdapat beberapa kelemahan-kelemahan. Hal ini dikarenakan perusahaan belum memiliki data yang lengkap dan akurat tentang kelayakan calon pengguna jasa untuk diberikan pelayanan jasa kapal secara kredit, perusahaan belum memiliki aturan yang terdokumentasi tentang batas maksimal pelayanan jasa kapal secara kredit yang dapat diberikan kepada pengguna jasa, perusahaan belum mengirim secara periodik kepada 
pengguna jasa konfirmasi piutang usaha pelayanan jasa kapal yang akan jatuh tempo dalam bulan yang bersangkutan, perusahaan belum memiliki kebijakan terdokumentasi untuk memotivasi pengguna jasa membayar lebih awal.

Berdasarkan analisis dan pembahasan yang telah dikemukakan sebelumnya, hipotesis yang diajukan dalam penelitian ini "Diterima" sebab diketahui bahwa pelaksanaan audit manajemen atas fungsi keuangan terhadap pengelolaan piutang usaha pelayanan jasa kapal mendapatkan hasil perhitungan presentase sebesar $46,4 \%$ yang berarti dikategorikan "Kurang Efektif".

\section{PENUTUP}

\section{A. Kesimpulan}

1. Perusahaan belum memiliki data yang lengkap dan akurat tentang kelayakan calon pengguna jasa untuk diberikan pelayanan jasa kapal secara kredit.

2. Perusahaan belum memiliki aturan yang terdokumentasi tentang batas maksimal pelayanan jasa kapal secara kredit yang dapat diberikan kepada pengguna jasa.

3. Perusahaan belum mengirim secara periodik kepada pengguna jasa konfirmasi piutang usaha pelayanan jasa kapal yang akan jatuh tempo dalam bulan yang bersangkutan.

4. Perusahaan belum memiliki kebijakan terdokumentasi untuk memotivasi pengguna jasa membayar lebih awal.

5. Pengelolaan piutang usaha pelayanan jasa kapal pada PT. Pelabuhan Indonesia IV (Persero) Cabang Samarinda masih kurang efektif, sehingga masih memerlukan perbaikan-perbaikan untuk meningkatkan efektivitas dari program tersebut.

\section{B. Saran}

1. PT. Pelabuhan Indonesia IV (Persero) Cabang Samarinda harus membuat persyaratan terkait data-data yang harus dilengkapi oleh calon pengguna jasa untuk dapat diberikan pelayanan jasa kapal secara kredit.

2. PT. Pelabuhan Indonesia IV (Persero) Cabang Samarinda harus membuat peraturan yang terdokumentasi terkait batasan maksimal pelayanan jasa kapal secara kredit yang dapat diberikan kepada pengguna jasa. 
3. PT. Pelabuhan Indonesia IV (Persero) Cabang Samarinda harus mengirim secara periodik kepada pengguna jasa konfirmasi piutang usaha pelayanan jasa kapal yang akan jatuh tempo dalam bulan yang bersangkutan.

4. PT. Pelabuhan Indonesia IV (Persero) Cabang Samarinda harus membuat kebijakan terdokumentasi untuk memotivasi pengguna jasa membayar lebih awal.

5. PT. Pelabuhan Indonesia IV (Persero) Cabang Samarinda harus melakukan pengawasan terhadap kinerja Sumber Daya Manusia (SDM) khususnya pada bagian supervisi piutang.

\section{DAFTAR PUSTAKA}

Agoes, Sukrisno. 2017. Auditing Petunjuk Praktis Pemeriksaan Akuntan oleh Akuntan Publik. Buku 1 Edisi 5. Jakarta: Salemba Empat.

.2019. Auditing Petunjuk Praktis Pemeriksaan Akuntan oleh Akuntan Publik. Buku 2 Edisi 5. Jakarta: Salemba Empat.

Arens. et, al. 2010. Auditing and Assurance Services: An Integrated Approach. 13 ${ }^{\text {th }}$ Edition. New Jersey: Pearson Prentice Hall.

Armaini, Rosy. 2016. Audit Operasional atas Pengelolaan Piutang Pada PT. Anugerah Wisata Tour \& Travel Palembang. Jurnal Akuntansi. Jurnal Akuntanika, No 2. ol. 1

https://academia.edu/23433769/Audit-Operasional-Atas-PengelolaanPiutang-Pada-PT-Anugerah-Wisata-Tour-and-Travel-Palembang

Bhayangkara, IBK. 2015. Audit Manajemen: Prosedur dan Implementasi. Edisi Kedua. Jakarta: Salemba Empat.

Champion, Dean J. 2015. Basic Statistik for Social Researc. (Jurnal). Lucia Oktaviana.

Halim, Abdul. 2015. Auditing 1 (Dasar-Dasar Audit Laporan Keuangan). Edisi Kelima. Yogyakarta: Unit Penerbit dan Percetakan Sekolah Tinggi Ilmu Manajemen YKPN.

Hery. 2017. Auditing dan Asurans (Pemeriksaan Akuntansi Berbasis Standar Audit Internasional). Jakarta: Grasindo.

Kieso, Weygandt and Warfield. 2012. Intermediate Accounting Volume 1 IFRS Edition. $10^{\text {th }}$ Edition. John Wiley \& Sons. Inc: United States of America. 
Mulyadi. 2014. Auditing. Buku 1 Edisi 6 Cetakan 9. Jakarta: Salemba Empat.

Nurima, Siti Nurul. 2016. Audit Manajemen Dalam Fungsi Keuangan Untuk Mengukur Efektivitas Dan Efisiensi Manajemen Keuangan PT. Bank Tabungan Negara (Persero). Tbk Surabaya. No. 4. Vol. 2

http://fe.ubhara.ac.id/ojs/index.php/equity/article/view/241

Priansa, Donni Juni dan Agus Garnida. 2013. Manajemen Perkantoran Efektif Efisien dan Profesional. Bandung: Alfabeta.

Sarapa, Djohariah. 2017. Audit Manajemen atas Fungsi Keuangan Pada PT. Megah Putra Sejahtera Makassar. Jurnal Aplikasi Manajemen, Ekonomi dan Bisnis. $\quad$ No. 2. Vol. 1

http://www.jameb.stimlasharanjaya.ac.id/JAMEB/article/view/27

Sari, Vernia Kartika. 2019. Audit Manajemen Atas Fungsi Piutang Fungsi Keuangan Terhadap Pengelolaan Piutang Dan Sistem Penerimaan Kas Pada PT. Kalindo Etam. No. 3. Vol. 8 http://ejurnal.untag-smd.ac.id/index.php/EKM/article/view/4236

Tandiontong, Mathius. 2016. Kualitas Audit dan Pengukurannya. Bandung: Alfabeta. 